\title{
On the Reform of Teaching Mode in Innovation Education-A Case Study of Financial Management Courses
}

\author{
Yuan Gao ${ }^{1, \text { a }}$ and Ye Zhao ${ }^{2, b}$ \\ ${ }^{1}$ School of Economics and Management, Changchun University of Technology, Changchun, Jilin, \\ China \\ ${ }^{2}$ School of Economics and Management, Changchun University of Technology, Changchun, Jilin, \\ China \\ a407222789@qq.com, bzhaoyejessie@hotmail.com
}

\author{
Keyword: Innovation Education, Teacher, Teaching Mode.
}

\begin{abstract}
Innovation is an important driving force for the development and progress of human society. In the meantime, innovation education is also the driving force of educational development. The innovation of teaching mode must be carried out in the development of innovative education. In order to cultivate students' innovative spirit, teachers should have the courage to innovate by reforming the classroom teaching and adopting diversified teaching modes.
\end{abstract}

\section{Introduction}

In twenty-first century, the society has become knowledge economy, enterprising and highly competitive. Society needs innovation, education needs innovation and needs more teachers with innovative quality. A significant objective, to give priority to the development of education and construct a country which riches in human resources, has been reported in the report of 17 th National Congress of the Communist Party of China. The duty of teachers in colleges and universities is to impart knowledge and educate people. Teachers should give full play to their role in the process of building human resources power, take the lead, do a good example, and cultivate more innovative talents. Teachers are engaged in creative work. Only when the teachers are full of innovative spirit can they cultivate innovative talents. Moreover, the most important thing in innovation education is the reform of teaching modes.

\section{The Necessity of Teaching Mode Reform}

Along with the Chinese higher education transforms from "elite education" to "popular education", the personnel training mode which aims at cultivating compound talents, innovation talents and applied talents has become the first choice in colleges and universities. Teaching mode must also adapt to the new requirements of personnel training mode and improve the quality and efficiency of teaching by reform and innovation.

The course of financial management is of great practical significance. It is not enough for the students to learn the theoretical knowledge from the books only by teachers' teaching. Colleges and universities should also make the traditional teaching methods of financial management reformed and innovated. The reform and innovation from the teaching mode can make students have a deeper understanding of the financial management courses and enable students to adapt to the needs of society and the market, thus, better apply the theoretical knowledge of the book to the actual work.

\section{The Basic Content of Teaching Model Reform}

The teaching model is the basic structure and the activity procedure about teaching activities, which includes certain teaching ways and methods. How to find a new teaching model, scientifically and reasonably organize the teaching process, and form a good quality and effective teaching methods, has become one of the important contents of college teaching reform. On the whole, the new teaching mode reform mainly has the following methods: 
3.1 Emphasis on Case Teaching Method The case teaching method refers to adopt case method to impart knowledge and skills in financial management teaching. It takes the issues that have occurred or may occur in the future in the real economic life as the case form to allow students to analysis and research, and puts forward various solutions or measures, and then makes a judgment and decisionmaking, so as to improve the students' analysis and the ability of solving practical problems. This is heuristic and interactive teaching method that benefits teachers as well as students. In the case teaching of financial management, the teacher should not only combine the case with the teaching content and practice, but also accord with the cognitive level of the students. Teacher ought to study the case type of teaching thoroughly, and then carry out the case teaching in the classroom. The right choice of cases and students' active participation can make case teaching play a role which is "refresher - though-provoking-practical analysis - improve ability".

In the process of implementing the case teaching, teachers should focus on the selection and organization of teaching cases and the power of controlling class which making students can better play the role of cases. The selection of cases can be divided into two categories. One is the classic cases that interspersed in the theoretical teaching. These cases are only the introduction of the basic theory knowledge. For example, when teacher teaches the time value of the money, he or she can tell the story of Matthew in the bible. Matthew called his three sons to bed when he was seriously ill, and he gave each son $\$ 100$. One year later, the three sons went back to Matthew's bed, the eldest son with only $\$ 50$, the second son did not move the $\$ 100$, and the third son's $\$ 100$ changes into $\$ 1000$ because of his hard work. Hence, Matthew called his eldest son and his second son to give their own $\$ 100$ to the third son, and the third son was in charge of the affairs of the family. This example is a good description to indicate that the currency is only into circulation and under the effect of average rate of profit can create value-added. Only by increasing the value of money can we create more wealth for the society. Another one is teachers should make use of training courses to organize students to do financial management case analysis of large listed companies. Such as investment decision analysis, accounts receivable decision analysis, the application analysis of the marginal cost of capital in the process of additional financing decisions. In case analysis, students need to find and organize information by their own and make courseware, and then explain the decision-making process to other students who are in the group until final decision-making conclusions are obtained. In the whole learning process, teachers are no longer subject but dominant, and students' subjective initiative can have achieved full play. The theoretical teaching is applied to the actual case analysis, and the students no longer feel bored and confused about what they have learned. Teachers can also be inspired from students speak and find out the shortcomings in the teaching and then improve it, which is called "to teach is to learn".

3.2 Attach Importance to the Application of Simulation Teaching Method and Field-based Teaching Method in Financial Management Simulation teaching method is to use computer tools to assist the process of simulation teaching and train students various management skills. The common simulation teaching methods include computer simulation, ERP simulation game teaching and laboratory simulation, etc. The precondition of simulation teaching is constructing a mathematical model to simulate continuously developing and changing environment in the enterprises operation. Teacher puts forward the decision problem and gives some basic conditions, such as the existing capital, production capacity and market share which are enterprise's internal conditions, and the market demand and competitive enterprise status which are enterprise's external conditions, and then students are required to make decisions on the given condition in the perspective of business managers. It can not only train students to use the existing knowledge to analyze and solve problems, but also help students develop decision-making capacity in a variety of complex and changeable marketing environment.

The field-based teaching method is to combine with the situation of the enterprise to teach theoretical knowledge. Part of the financial management and the reality of the industrial and commercial enterprises are closely linked, such as the credit financing. It is difficult for students who do not understand the process of bank credit to give appropriate advice when discussing case. If adopting the field-based teaching method to teach this part, the classroom will move to bank credit 
department, and the credit officers will explain the operation of credit funds personally, so that students will have a more profound understanding. In field-based teaching, teachers can also go to the enterprise to learn and video first, and then teach courses according to the scene recorded, or use computer software to simulate the scene. Different enterprises for the same content layout of the site may not be the same because of enterprises' different actual needs. Teachers should pay attention to the difference when using this teaching method.

3.3 Increase the Situational Teaching Method The situational teaching method is that the teacher designs the vivid images and pictures according to the description of the teaching content that supplemented lively language, and reproduces the scene representation of teaching content with the artistic appeal of music to enable students to feel be involved. It is a teaching activity that makes teachers and students are in a situation with the scenery depicted and the emotions expressed in perfect harmony.

Situational teaching method can help to explain the financial management theory, financial management methods and financial management practices, which are difficult to express clearly in traditional teaching methods, through computer network simulation experiment class, teaching software and multimedia courseware. For example, when explaining the activity-based costing, it is necessary to clarify that when companies expand their product lines, manufacturing processes often become more complex, and it is very important to accurately allocate the manufacturing cost for the enterprises which produce a variety of products; moreover, the defect of using the traditional method to allocate the manufacturing costs, so the distribution basis should change into cost drivers. This requires students to understand the manufacturing process. Nevertheless, students' social experiences are quiet poor. If teachers utilize animation, picture and sound to design multimedia courseware and match them with the teaching can make the students easily understand and master. More examples, teachers can demonstrate the full process of preparing budget and financial analysis to students through teaching software of financial management, or let students be visitors at a phone or video meeting about comprehensive budget management of the enterprise, or utilize the "Cash Pooling" of UF ERP-NC software to show how the group company monitors the cash flow and flow direction of their members and allocates funds by administrative means, etc. It is a way to make students have a comprehensive understanding of the whole process of financial management.

3.4 Increase the Application of Network Discussion Method in Financial Management The network discussion method is that teachers use the feature of computer network that are information sharing, rapid transfer function and interactive multimedia information to two-way communicate directly with students on screen through the network in the computer network simulation experiment classroom. It means that students can ask teachers questions through their own computers, teachers can answer students' questions and guide the students to solve the problems on their own computers, and teachers can also display students' learning outcomes for every student online. This way can enable students to seek answers by their own thinking and online interaction communication, and then evaluation on the internet. In addition, students can also send or receive messages via e-mail. In the process of comprehensive budget teaching, for example, the students are preparing the daily business budget, special decision budget and financial budget separately on their own computers, when the students who prepare the cash budget need the sales budget, material budget, labor budget and capital expenditure budget, they can directly obtain information from other students through the network, and then complete the cash budget.

\section{Conclusion}

Overall, the teaching based on the case with other flexible and vivid teaching methods not only can enhance students' interest in learning financial management or understand the basic theory of financial management, but also cultivate students' learning ability and innovative thinking. However, each teaching method has some limitations, teachers require to teach students in accordance with their aptitude. In order to achieve better teaching effect in the teaching process, teachers can flexibly use one or several methods combing with specific content and context.

The teaching methods of these teaching modes are comprehensive. There are both dictation and 
blackboard writing and modern teaching ways on the basis of multimedia technology, computer technology and network technology. Teachers employ effective teaching intermediary to achieve interactive teaching, improve teaching effectiveness and provide students rich and varied learning style and development environment.

\section{References}

[1] L. N. Wang and X. H. Yu, The application of case teaching methodology in financial management teaching, Communication of Finance and Accounting (Integrated), vol. 2, pp. 16, 2009.

[2] W. F. Xiao and L. Xiao, Several thoughts on the teaching method of financial management courses, Friends of Accounting, vol.5, 2010.

[3] A. J. Zeng, Discussion on the teaching mode of financial management course for non-accounting major, Journal of Hubei University of Economics (Humanities and Social Sciences), vol. 4, 2012.

[4] Y. Sun, Study on reform and innovation of financial management, Reform and Exploration, vol. $1,2015$. 